\title{
State Management of Food Security as a Factor of Sustainable Development of the Region
}

\author{
Dmitry Loginov*
}

\author{
Vyatka State University, Kirov, Russia \\ ${ }^{*}$ Corresponding author. Email: doctorloginov@mail.ru
}

\begin{abstract}
Effective management of food security on a national scale helps to achieve a high level of well-being of society. In modern conditions, the role of food security indicators that characterize the economic availability of food is increasing. The present study is aimed at improving the range of indicators of food security, taking into account the evolution of views on the essence of food security. For this purpose, possible ways of expanding food security indicators are considered, and in the process of dynamic analysis of indicators, the feasibility of using them to measure the level and general characteristics of food security is justified. New socially significant indicators of food security are proposed from among those indicators of economic security that are currently considered by state statistics bodies as general indicators of economic security. The results of the study can be used in the activities of state authorities at the national and regional levels in the process of improving the state agrarian policy.
\end{abstract}

Keywords: sustainable development, region, food security, state management.

\section{INTRODUCTION}

Building an optimal state management of the agroindustrial complex in modern conditions is a very difficult task. This is due to the need to rethink the priorities facing the state administration of the agricultural sector of the economy and those related industries that are technologically related to agriculture. Considering the state management of the agro-industrial complex, it is necessary to be aware of the fact that agriculture today is mostly private production associated with the implementation of an entrepreneurial initiative. In this context, it is necessary to clearly define what priorities the state provides by participating in the management of this segment of economic life.

The volume of agricultural production in conditions of predominance of private ownership is the result of the regulatory forces of the market, in which the state, as a rule, can interfere very limited. In this case, the question arises about the need to understand the subject and object of state management of the agro-industrial complex. One of the possible goals of state management of the agroindustrial complex may be to ensure food security. Indeed, it is the state of ensuring food security that can be considered as the priority that the whole society is interested in achieving. Thus, it is food security that could be considered as a key criterion for the organization of modern state management of the agro-industrial complex.

Food security as a criterion of state management of the agro-industrial complex is considered by the author of this article as a working hypothesis of the presented study.

The purpose of this study is to assess the current state of state activities to ensure food security and correlate these efforts with the assessment of the state of state management of the agro-industrial complex, as well as to propose approaches to improving state management of the agro-industrial complex in the paradigm of food security activities.

The following research tasks follow from this goal:

- to assess the current state of ideas about the role of food security in determining the criteria for the development of state management of the agro-industrial complex;

— to identify the features of the current state of state management of the agro-industrial complex;

- to propose ways to improve food security within the framework of state management of the agro-industrial complex; 
- to substantiate approaches to finalizing the mechanism of state management of the agro-industrial complex from the standpoint of ensuring food security priorities.

\section{MATERIALS AND METHODS}

There are more and more studies on the state policy of ensuring food security in the world science [1]. There is an intensification of Russian research in this area. At the same time, much attention is paid to the study of the relationship between the state of agriculture and the level of food security of the country [2].

The researchers focus on the development of the theory of food security from the standpoint of ensuring and increasing the availability of food [3]. The progress of the considered research direction is particularly clearly revealed in such an area as the identification of the driving forces for the development of food security [4]. A separate direction in the research of food security remains the analysis of food independence, its essence and driving forces, including at the regional level [5].

Published scientific papers have collected strong evidence in favor of the fact that ensuring food security should be a state matter [6]. Rather narrow functional areas of agro-industrial activity that affect the development of food security in general have been identified [7]. For such large countries as Russia, the issue of creating and developing the foundations for ensuring regional economic security, including through regional government institutions, remains relevant [8].

The research material includes data on the state of agriculture in the Russian Federation, indicators of the development of the agricultural sector in our country, best practices for ensuring food security, as well as publications of specialists in the field of food security. The author summarizes his personal observations and professional experience.

The present study is based on numerous literature materials on ensuring food security at the state level. In this context, the key research method is the monographic method.

In addition, the method of quantitative analysis of statistical data was used in the study. In particular, the system of indicators included in the range of indicators of economic security of the Russian Federation is analyzed.

The method of organizational modeling is also applied. It is used in relation to the selection of approaches to the creation of a system for making effective managerial decisions in the process of state management of the agro-industrial complex.

Understanding the role of food security in ensuring effective state management of the agro-industrial complex requires understanding the origin of food security as a phenomenon and a criterion for public administration. The scientific literature pays great attention to national security and its isolation among the sciences. Most often, reference is made to the fact that national security as a science and practical activity of government bodies became isolated in the twentieth century, which was due to the increase and increase in the scale of threats to humanity and individual countries.

National security is the highest category in the hierarchy of various security categories. Within the national security, as a rule, separate types of security are distinguished, including economic security, which is given the most attention in this study.

In addition, within the security category, it is customary to distinguish the category of independence, which characterizes, as a rule, a separate side of security related to the ability to avoid negative consequences of security threats.

An important aspect of the differentiation of the concept of economic security is the allocation of separate sectoral areas of security within this category. One of these sectoral areas of economic security is food security.

As a rule, the importance of food security is determined by the role of the agro-industrial complex in the life of society and each individual person.

However, the author of this study believes that the importance of food security is broader than the role of the agro-industrial complex and extends to the field of social security.

\section{RESULTS AND DISCUSSION}

The official interpretation of the criteria of Russia's national food security is based on the ideas of food independence. As a key goal of ensuring food security, it is considered to increase the production of domestic food to the extent that it will definitely prevail over the import of the corresponding type of food.

There is also a broader view based on the assumption that not every threat to the agro-industrial complex is reduced to the dominance of imported resources in the food market. There may also be specific, unique threats that did not have any analogues before, and therefore the agro-industrial complex must find ways to counter such threats.

In particular, one of such new threats hanging over the agro-industrial complex is the reduction of the possibility of purchasing foreign technologies abroad, as well as breeding achievements. All this stops scientific and technological progress in agriculture, reduces the possibility of transition to innovative development, slows down innovative progress in the industry.

Considering this threat, we can see how important the import substitution argument is in further strengthening 
Russia's food security. The emphasis on import substitution was made in many countries of the world at those stages of the development of the national economy when it was necessary to ensure a breakthrough in economic development. At the same time, the greatest emphasis was placed on those sectors of the economy that were considered the most labor-intensive and investment-intensive. In this regard, Russian agriculture can be quite recognized as the branch of the economy in which import substitution needs state support.

The direction of ensuring economic security has been clearly outlined in the Russian state economic policy. In this regard, a number of economic indicators are identified, which are officially recognized as indicators of economic security. There are no specially isolated indicators of food security among them. However, it is possible to identify those officially recognized indicators of the economic security of the Russian state that are closely related to ensuring food security.

The share of imports in Russian food resources has decreased significantly over the past 15 years: from 36 to $28 \%$, or 1.3 times. Such a change can be considered a definitely positive contribution to ensuring Russia's food security, in particular from the point of view of food independence. After all, now the Russian consumer is more likely to purchase domestic food or food products made from domestic raw materials, which undoubtedly has a positive impact on the development of the Russian agro-industrial complex, and on the national economy of Russia as a whole.

But is this shift enough? Answering this question, we must determine the criterion of sufficiency of import substitution in the food market. From our point of view, import substitution for those types of food that can be produced on the territory of their country under agroclimatic conditions should be complete. The exception should be only those food products that are not allowed to be produced on the territory of their country by agroclimatic conditions. For Russia, this is, first of all, a number of names of tropical fruits. Thus, the minimum level of the share of imported food that was achieved in our country in 2016-2017 should not be considered a limit that ensures food security in terms of independence from imports. It is necessary to set new target levels for further reducing the share of imports in the Russian market of food products.

The stratification of the population by income significantly affects the food market. This is due to the fact that when the stratification indicator goes beyond the critical (threshold) values, a situation occurs that is dangerous in terms of the safety of the middle class. It is the middle class that provides the main sales in the food market, having the opportunity to purchase an expanded relatively minimal set of food products. In this regard, the indicator of the fund ratio is quite directly related to the implementation of food security policy. We can argue that an increase in the fund ratio poses a threat to the food well-being of the majority of the population, including the middle class, the lower-middle class and the lowincome segments of the population. This once again confirms that ensuring the country's food security is not only an economic issue, but also a social one. The indicator of the fund coefficient (the decile coefficient of funds) for the period 2006-2007 worsened, and in the future it was practically fixed at the same level with a slight tendency to improve.

There were no sharp shifts towards improving the well-being of the population during the entire period under review. However, in 2019-2020, the trend of stratification of the population changed towards equalization, and in 2020 the best indicator of the decile coefficient of funds for the period since 2006 was achieved. Obviously, this may be due to the strengthening of the social orientation of the state economic policy in 2020, the implementation of a number of new social initiatives and the beginning of an active phase of the fight against poverty, announced in early 2020.

From our point of view, the decile coefficient of funds should be included among the indicators of economic security, since it directly affects the solvency of the majority of the population and the formation of the middle class in the country. At the same time, a value of at least 7 should be considered as a planned indicator of the coefficient.

The share of the population with low-income incomes below the subsistence minimum characterizes the presence of that segment of the population who, when choosing food products, will prefer cheap ones, guided by the limited capabilities of their budget. It should be understood that any significant share of such a population in the market significantly reduces the demand for food, restricts the development of the food market and corrects the structure of demand for food in the direction of the cheapest, high-calorie, but harmful to health with regular consumption of food. These are, first of all, highcarbohydrate foods that poor people choose to fill their energy needs with minimal costs. Such products include, first of all, bread products, pasta, potatoes. The predominance of such products in the Russian diet cannot characterize the food security of the nation as an established state.

Since 2006 , there has been a fairly stable tendency to reduce the population with monetary incomes below the minimum subsistence level.

The most prosperous year for this indicator should be considered 2012, when the share of the poor population decreased to $10.7 \%$. In the future, the picture began to change again in the direction of deterioration, but it did not reach such a dangerous state as was observed in 20052006. 
Moreover, in 2016, there was again a tendency to reduce the share of the poor population. This trend continues to the present time. Judging by the current pace, the minimum level reached in 2012 could be reached again in the next five years, that is, by 2026 .

Nevertheless, we consider it necessary to attribute the indicator of the population with monetary incomes below the subsistence minimum to the number of modern indicators of food security and plan the target (threshold) level of this indicator in the amount of half of the best indicator achieved over the past 15 years. This means that the level of the 2012 indicator should be halved, getting the value of $5.4 \%$. We believe that achieving this threshold value of food security will help increase the demand on the Russian food market for those food products that are considered the most valuable and useful for maintaining health and longevity, which are traditionally considered meat, fish, dairy products, fruits, vegetables and herbs. The Russian population should consume more products rich in protein and fiber. This will allow us to solve the problem of increasing the average life expectancy of the population and reduce the burden on the health and social security system. It is known that a deficiency of protein and fiber in the diet provokes the development of alimentary-dependent organic human diseases and, above all, disorders of carbohydrate and fat metabolism, which leads to an increase in the incidence of cardiovascular diseases.

Monitoring of food demand is of great importance in the development of the Institute of Food Security. Demand largely determines the fate of supply. In relation to the agro-industrial complex, demand and its structure determine both the volume of potentially possible products for production and the structure of food produced. In this regard, the dynamics of retail trade can be considered as an indirect sign of the dynamics of demand for food products, given that a significant part of retail trade is focused on food.

In 2005-2008, there was a steadily positive dynamics of retail trade in Russia with significant annual growth rates.

In 2009, there was a decline in retail trade, which was caused by the influence of the acute phase of the economic crisis of 2008-2009. However, in 2010, the growth of retail trade recovered, compensated for the decline in 2009, and since 2011, the volume of retail trade began to grow further (although at a slower pace), exceeding the level of 2008 .

The situation in 2015-2016, characterized by a steady decline in retail sales for two consecutive years, can be called more difficult than the situation in 2009, since the depth of the fall in trade over these two years turned out to be deeper. Of course, this had a corresponding impact on the food market, reducing the chances of those producers who expected to increase sales of high-margin, especially valuable types of food. There is a threat of shifting the focus of demand for food with a low content of protein and fiber and with a predominance of energy value. During 2017-2019, the growth rate of retail trade, although positive, was characterized by low absolute values, which did not even allow to compensate for the losses that occurred in 2015-2016.

Thus, in order to ensure food security, the growth rate of the physical volume of retail trade should be at least positive every year.

The acceleration of food inflation has exposed the problem of vulnerability of the population to the problem of economic availability of food. A rapid increase in prices for certain types of food was observed both in 2020 and in 2021. However, the picture of food inflation in 2019-2020 is not so dramatic compared to 2005, 2009, 2011, 2014-2015.

\section{CONCLUSION}

When building a state policy for managing the development of the agro-industrial complex, it should be taken into account that ensuring the economic availability of food is achieved not only by establishing control over the prices of certain types of food, but also by supporting investors who invest in the expansion and opening of new food production facilities. The way to stimulate supply is the most optimal approach to protecting the population from the threats of accelerating food inflation.

Currently, the role of food security in ensuring national economic security is increasing, which is due to the role of food security in ensuring the social well-being of the population.

In the formation of ideas about the criteria of food security, the emphasis should be shifted from the priority of ensuring food independence to ensuring the economic accessibility of food to the population.

To date, full food independence has not yet been achieved, which is confirmed by the noticeable share of imports in food resources, the value of which is characterized by the presence of a reserve for further reduction.

It is proposed to expand the range of indicators of food security in the direction of supplementing indicators that characterize food independence with indicators that characterize the economic availability of food. For this purpose, it is proposed to use certain currently observed indicators of economic security, including the share of imported food products in the commodity resources of the retail trade in food products, the fund ratio (the ratio of monetary incomes of the $10 \%$ of the most and $10 \%$ of the least well-off population), the number of people with monetary incomes below the subsistence minimum, the increase in consumer prices for food products. 


\section{REFERENCES}

[1] M. Rusliyadi, A.B.H.M. Jamil, R.T. Kumalasari, Analysis of household food security policy: case of food security village programme, Indonesia. Asian Journal of Agriculture and Rural Development 9(1) 2019 pp. 19 - 32. DOI: https://d oi.org/10.18488/journal.1005/2019.9.1/1005.1.19.3 2.

[2] I.A. Boldyreva, O.G. Andryushchenko, A.Yu. Nikitaeva, Z.V. Udalova, Ja, The agricultural production and food industry development trends in the context of food security of Russia. Journal of Environmental Management and Tourism 137 4(20) (2017) pp. 642-647. DOI: https://doi.org/10.14505/jemt.v8.3(19).15.

[3] R. Mudrak, Yu. Tsymbalyuk, L. Fytsyk, Aaffordability of food as a key condition of food security of households. Economic Journal-XXI 168 (11-12) (2017) pp. 53-56. DOI: https://doi.org/10.21003/ea.V168-11.

[4] R.R. Galiev, H.D. Ahrens, Stochastic model checking, In: M. Bernardo, J. Hillston (Eds.), Determinants of food self-sufficiency in Russia and food security. Studies on Russian Economic Development 32(3) (2021) pp. 254-262. DOI: https://doi.org/10.1134/S1075700721030059.

[5] S.V. Gubarkov, I.V. Zhuplei, N.A. Tretyak, Food independence as key component of food security of the Far eastern federal district, In: IOP Conference Series: Earth and Environmental Science International science and technology conference "Earth science", 2021, p. 052042. DOI: https://doi.org/10.1088/17551315/666/5/0520 42.

[6] G.E. Omarova, S.S. Ydyrys, B.A. Markhayeva, Z.E. Abilgazieyeva, G.R. Duisembekova, E.T. Nurmaganbet, Ways to improve the protection of national food security by the state. Espacios 38(18) (2017) p. 18.

[7] A. Ivolga, V. Trukhachev, N. Bannikova, A. Baicherova. Jha, Improvement of food security through reforming of domestic veterinary service: case of Russia. Establishing Food Security and Alternatives to International Trade in Emerging Economies, 2017 pp. 337-358. DOI: https://doi.org/10.4018/978-1-5225-2733-6.ch016.

[8] E.B. Naidanova, N.M. Polyanskaya, Provision of food security of a region based on the example of the Republic of Buratia. Studies on Russian Economic Development 28(1) 2017 pp. 52-59. DOI: https://doi.org/10.1134/S1075700717010087. 